Dokuz Eylül Üniversitesi-Mühendislik Fakültesi

Fen ve Mühendislik Dergisi

Cilt 20, Sayı 58, Ocak, 2018
Dokuz EylulUniversity-Faculty of Engineering Journal of ScienceandEngineering Volume 20, Issue 58, January, 2018

DOI: $10.21205 /$ deufmd.2018205818

\title{
Kent İçi Ulaşımda Yolculuk Amacına Bağlı Güvenilirlik Algısının İncelenmesi: Tınaztepe Kampüsü Öğrenci Erişimi Örneği
}

\author{
Mustafa ÖZUYSAL ${ }^{* 1}$, Derya KAYA ${ }^{2}$ \\ ${ }^{1}$ Dokuz Eylül Üniversitesi, Mühendislik Fakültesi, İnşaat Mühendisliği Bölümü, 35160, \\ İzmir (ORCID: 0000-0002-3276-3075) \\ 2Dokuz Eylül Üniversitesi, Mühendislik Fakültesi, İnşaat Mühendisliği Bölümü, 35160,
} İzmir (ORCID: 0000-0003-1517-9405)

(Alınış / Received: 25.07.2017, Kabul / Accepted: 20.09.2017, Online Yayınlanma/ Published Online: 20.01.2018)

Anahtar Kelimeler Özet: Toplu ulaşımda güvenilirlik, önceden planlanan bir Güvenilirlik, Yolculuk Amacı, Toplu Ulaşım, Belirtilen Tercih Anketi, Çoklu Lojistik Regresyon çizelgelemeye ya da belirlenmiş sefer aralıklarına ve sabit bir yolculuk süresine bağlı kalabilme yeteneği olarak tanımlanmaktadır. Güvenilirliğin özellikle metropol kentlerde yüksek düzeyde olması beklenmekte, bunu sağlamak için ise özel taşıt trafiğinden bağımsız çalışan raylı sistemler, eş zamanlı yolcu bilgilendirme sistemleri gibi yüksek maliyetli yatırımlara ihtiyaç duyulmaktadır. $\mathrm{Bu}$ yatırımlardan sağlanacak toplumsal fayda, güvenilirliğin boyutundan ziyade, kullanıcılar tarafından nasıl algılandığına bağlıdır. Bu çalışmada, yatırımların güvenilirlik bakımından fayda analizi için parametrik bir destek verisi geliştirilmesi amaçlanmış; güvenilirlik algısında yolculuk amacı ve kişisel özelliklerin etkili olup olmadığı araștırılmıştır. Belirtilen tercih anketi yardımıyla toplanan verilerden hareketle, çoklu lojistik regresyonlar oluşturularak parametrik modeller geliştirilmiștir. Model bulguları incelendiğinde, derse gelirken tür seçiminde, cinsiyet, üniversitede 1 ila 3 yıl süreyle bulunma, toplu ulaşım kullanıyor olma gibi parametrelerin, daha yüksek güvenilirlik algısı olușturan aktarmasız alternatiflere yönelmede etkili olduğu bulunmuştur. Yüksek risk alma davranışının sınandığı güvenilirlik senaryosunda ise aktarmada metro kullanmayanlar ile şehirde uzun süredir yaşayanların güvenilirlikte daha büyük risk alarak yolculuk süresini kısaltmak istedikleri ortaya çıkmıştır. Sonuç olarak güvenilirliğin kişiden kişiye hatta aynı kişinin farklı amaçlı yolculuklarında dahi farklı algılandığı, dolayısıyla ulaşım talep modellerinde bir maliyet ağırlıklandırma bileşeni olarak değil; yaş, cinsiyet, gelir vb. gibi başlı bașına bir sosyo-ekonomik parametre gibi değerlendirilmesi gerektiği anlașılmıștır. 


\section{Investigation of Reliability Perception Based on Trip Purpose in Urban Transportation: Case Study on Student Access to Tinaztepe Campus}

\begin{tabular}{l}
\hline Keywords \\
Reliability, \\
Trip Purpose, \\
Public \\
Transportation, \\
Stated Preference \\
Survey, \\
Polytomous \\
Logistic \\
Regression
\end{tabular}

Abstract: Reliability is defined as the ability to adhere to a preplanned schedule or to defined intervals and a fixed travel time. Reliability is expected to be high particularly in metropolitan cities. To achieve this, high-cost investments such as rail systems that are operated independently of private vehicle traffic and simultaneous passenger information systems are needed. The social benefit to be made from these investments depends largely on how it is perceived, rather than the magnitude of the reliability. In this study, it is aimed to develop a parametric support data for benefit analysis of investments in terms of reliability. It is investigated whether the purpose of travel and personal characteristics are effective in the sense of reliability or not. Parametric models are developed by using multiple logistic regressions with the collected data by the help of the stated preference survey. When the model findings are examined, it is found that parameters such as gender, presence at the university for 1-3 years, use of public transportation, etc. are effective in tending to direct transportation modes that constitute a higher sense of reliability. In the reliability scenario model testing the high risk taking behavior, it is found that disability for using metro as a transfer alternative and living for a long time in the city generate a tendency to shorten the travel time by taking more risks in reliability. It is concluded that reliability is perceived differently, even on different trip purposes of the same person, and therefore it should be considered as a socio-economic parameter like age, gender, income, etc. on its own, rather than a cost weighting component in transportation demand models.

*Sorumlu yazar: mustafa.ozuysal@deu.edu.tr

\section{Giris}

Yolculuk süresi belirsizliği günlük hayatımızın kaçınılmaz bir parçasıdır. Ampirik anketler yolculuk süresi belirsizliğinin / güvenilirliğin yolcuların güzergâh ve kalkış saati seçiminde önemli bir rol oynadığını doğrulamıştır. Bununla birlikte, geleneksel trafik modelleri ve toplu ulaşım çizelgeleme çalışmalarının çoğu, yolculuk kararının alınmasında belirsizliğin rolü ve yolculuk süresinin stokastik niteliğini yeterince ele almamaktadır. Dakikliğe duyarlı yolcuların, rastgele kapasite yetersizliği, talep dalgalanmaları ve dişsal kaynaklardan gelen yolculuk süresi belirsizliklerini dikkate alan ağ denge modellerinde birbirleriyle etkileşime girdikleri, birbirlerinin kararlarından etkilendikleri bilinmektedir [1].

Yolculuk süresi belirsizliğinin ulaşım ağları üzerindeki etkisini incelemek için ilk adım, belirsizlik durumundaki yolculuk seçimi davranışının incelenmesidir. Günlük yolculuk kararlarında yolcular, ulaşım türü ve evden ayrılıș zamanı tercihlerini, memnuniyetini veya faydayl en üst düzeye çıkaracak şekilde ayarlamaktadır. Genel olarak, seçim modelleri (beklenen) fayda maksimizasyonu veya (beklenen) maliyet minimizasyonu kavramına dayalı olarak geliştirilmektedir. Birçok köklü 
araştırma modelinde yolculuk süresi riski, ortalama yolculuk süresi ile benzer șekilde, yolculuk süresi değișkenliğine ilişkin bir ağırlıklandırma katsayısı ekleyerek veya zamanlama (evden ayrılış zamanı) kararını ayarlayarak yansitılmaktadır [1]. Small [2] trafik atama modelinde, yolcular için yalnızca trafik tıkanıklığına bağlı olarak değil, aynı zamanda istenen programa uyulmaması nedeniyle (yani toplu ulaşım taşıtı çok erken veya çok geç ulaştığında) bir sürtünme parametresi uygulanmasını önermiștir.

Güvenilirlik, toplu ulaşım sisteminin bir çizelgelemeye ya da daha önceden belirlenmiş sefer aralıklarına ve sabit bir yolculuk süresine bağlı kalma kabiliyeti olarak tanımlanabilmektedir [3]. Toplu ulaşım sistemlerinde güvenilirlik, yolcular ve işletmeciler açısından çok önemli bir yere sahiptir. Güvenilirliğin göz ardı edilmesi yolcular için bekleme sürelerinin artışına, düzensiz araç sıklıkları nedeniyle konforsuzluğa neden olmaktadır. İşletmeciler açısından ise ölü mesafe ve işletme maliyeti artışına, ayrica filodan yararlanma oranının azalmasına yol açmaktadır. Bununla birlikte, yapılan çalışmalar güvenilirliğin yolcuların tür seçimlerini de etkilediğini göstermektedir $[4,5,6]$.

Güvenilirlik, toplu ulaşım sisteminin işletme karakteristikleriyle ilişkili olan hizmet kalitesi ölçme yöntemidir [7]. Abkowitz vd. [8], güvenilirliği toplu ulaşım işletmecilerinin ve yolcuların karar verme süreçlerini etkileyen servis özelliklerindeki süreklilik olarak tanımlamıştır. Güvenilirlikle ilgili yapılan çalışmalarda temel olarak toplam yolculuk süresinin ve temel bileşenlerinin tahmin edilmesi konusu incelenmektedir. Özellikle yolculuk süresindeki değişkenlik yolcuları iki farklı şekilde etkilemektedir [9]:
- Güvenilir olmayan servislerin toplam yolculuk süresi ve bekleme süresinin tahmin edilememesi,

- Güvenilir olmayan servislerin, yolcuların faydasızlığı minimize edilmesini amaçlayan en uygun yolculuk seçeneği kararını vermesini engellemesi.

Dolayısıyla yolculuk karar sürecinde güvenilirliğinin rolünü incelemek gereklidir. Modelleme aşaması için özellikle şu soruların cevaplanması gerekmektedir:

- Güvenilirlik, fayda fonksiyonunda bir maliyet ölçeklendirme bileşeni midir? Değilse ayrı bir bileşen veya boyut olarak değerlendirilebilir mi?

- Güvenilirlik gelir, yaş ve cinsiyet gibi kişisel bir özellik midir? Değilse ulaşım ağının bir unsuru gibi düşünülebilir mi? [1]

$\mathrm{Bu}$ nedenle, güvenilirliğin kişinin karar vermesine nasıl yansıdığına ilişkin mekanizma, ampirik kanıtlarla dikkatli bir şekilde incelenmelidir. Bu çalışmada, ulaşım sistemi yolculuk süresi güvenilirliğinin, yolcular tarafından algılanma şekli irdelenmiştir. Güvenilirlik algısı iki farklı şekilde sınanmış; öncelikle farklı güvenilirlik algısı oluşturan toplu ulaşım alternatiflerinin tercih sebepleri, ardından süre tasarruf veya kaybı ihtimallerine karşı risk alma davranışları, parametrik modellerle açılanmaya çalışılmıştır. Böylece, güvenilirliğin bir varyans bileşeninden ziyade, oluşturduğu etkinin farklı yolcu özellikleri ve amaçlarına göre değerlendirilmesinin sağlanması, bu sayede ulaşım sisteminde yapılacak güvenilirliği arttırmaya yönelik yatırımların daha sonuç odaklı olması için bir karar destek verisi oluşturulması amaçlanmıştır. 
Davranış modellerini doğrulamada en çok kullanılan ampirik yöntemler, "belirtilen tercih" [10] veya "ortaya konan tercih" [11] anketleri gibi doğrudan yöntemler veya döngüsel dedektör verileriyle yolculuk süresi değişkenliğini kalibre eden dolaylı yöntemler [12] olabilmektedir [1]. Bu çalışmada ulaşım kararlarının analizinde sıkça kullanılan, "belirtilen tercih" anket yaklaşımından yararlanılmıştır. Turistik bölgelerde uygulanan erişim politikalarının etkilerinin değerlendirilmesi [13], yeni raylı sistemlerin günlük iş yolculuklarındaki tür seçimine etkisinin araştırılması [14], Pekin'de yolculuk süresi güvenilirliğinin, yine iş yolculuğu yapanlar tarafindan nasıl dikkate alındığının modellenmesi [15] gibi belirtilen tercih anketine dayalı çalışmalar, bu yöntemin tercihinde etkili olmuştur. Sosyo-ekonomik ve ulaşımaktivite çeşitliliği bakımından türdeşe yakın bir örneklem elde etmek amacıyla, İzmir'in Buca ilçesindeki Dokuz Eylül Üniversitesi (DEÜ) Tınaztepe Kampüsü'nde öğrenim gören 180 öğrenci katılımcı üzerinde çoktan seçmeli olarak düzenlenen bir "belirtilen tercihler" anketi uygulanmıştır. Çalışmanın ikinci bölümünün ilk kısmında, uygulanan ankete ilişkin bilgiler verilmiştir. Anket sonucu elde edilen veriler kullanılarak, güvenilirlik algısının bağımlı değişken olduğu çoklu lojistik regresyon modelleri oluşturulmuştur. Lojistik regresyon modeli, çoktan seçmeli cevaplarda olduğu gibi ayrık bağımlı değişkenlerin kullanıldığı birçok alanda standart bir analiz yöntemine dönüşmüştür [16]. Bu model yapısına ilişkin detaylar ikinci bölümün ikinci kısmında aktarılmıştır. Üçüncü bölümde, anket verilerinden, tür seçim ve güvenilirlik modellerinden elde edilen bulgular aktarılmıș, son bölümde ise bulgulardan elde edilen çıkarımlar tartışılmıştır.

\section{Materyal ve Metot}

Çalışma için öncelikle belirtilen tercih anketi oluşturulup uygulanmıştır. Bu ankette güvenilirlik algısında etken olabilecek kişisel veriler sorulmuş, ardından güvenilirlik algısını ölçmeye yarayan varsayımsal ulaşım türlerine ve güvenilirlik senaryolarına ilișkin cevaplar elde edilmiștir. Elde edilen veriler yardımıyla, farklı güvenilirlik düzeyleri öneren ulaşım türleri ve farklı düzeyde risk içeren güvenilirlik senaryoları için çoklu lojistik regresyon modelleri oluşturulmuştur. Kullanılan anket ve model kurgusuna ilişkin detaylar iki başlık halinde aşağıda detaylandırılmıştır.

\subsection{Belirtilen tercih anketi}

Yanıtlayan kişilere, gerçek durumları tecrübe etme zorunluluğu olmaksızın, varsayımsal durumların sunulduğu ve her bir sunulan alternatife ait özelliklere dayalı olarak seçim yapmaları istenen anketlere belirtilen tercih anketi denilmektedir. $\mathrm{Bu}$ anketler genellikle, alternatifler için fayda fonksiyonunu tahmin etmeye odaklanmış, ortaya konan tercih yönteminin çok popüler bir alt sinıfidir [17].

Çalışmada kullanılan anketin kurgulanmasında, 2003 yılında Hong Kong Bilim ve Teknoloji Üniversitesi (HKUST) tarafindan gerçekleştirilen çalışmadan yararlanılmış [1] çalışmadaki anket sadeleştirilerek İzmir ulaştırma altyapısı ve DEÜ Tınaztepe Kampüsü'nün erişim olanaklarına uyarlanmıştır.

Çoğunluğunu DEÜ Mühendislik Fakültesi öğrencilerinin oluşturduğu toplam 180 katılımciya anket formu açılanıp dağıtıldıktan bir süre sonra toplanarak gerçekleștirilen anket iki bölümden oluşmaktadır. Birinci kısımda, katılımcının cinsiyeti, yaşı, üniversitedeki yılı, İzmir'de bulunma süresi (yll), İzmir'de oturduğu ilçe, kampüse gelirken 
M. Özuysal ve D. Kaya / Kent İçi Ulaşımda Yolculuk Amacına Bağlı Güvenilirlik Algısının İncelenmesi: Tinaztepe Kampüsü Öğrenci Erişimi Örneği

toplu taşıma kullanıp kullanmadığı, ne sıklıkla toplu taşıma kullandığı, en sık kullandığı güzergâhta aktarma yapıp yapmadığı, aktarma yapıyorsa kaç farklı ulaşım türünü beraber kullandığı ve toplu taşıma türü seçiminde en önemli etkenin ne olduğu gibi sorular sorulmuştur. Kişisel ve temel ulașım davranışı tercihlerini içeren birinci kısım cevapları çalışmada sunulan modellerde açıklayıcı (bağımsız) değişkenleri oluşturmuştur. Elde edilecek verilerin tamamının kategorik olması ve cevaplama kolaylığı için tüm sorular çoktan seçmeli formatta düzenlenmiştir. Sorular ve 0-1 şeklinde sayısallaştırılıp model için kukla değişkene dönüştürülen seçenekler Tablo 1'de verilmiştir.

Anketin ikinci kısmında iki temel bölümde varsayımsal ulaşım tercihleri sorulmuş ve elde edilen cevaplar farklı modeller için bağımlı değişkenleri oluşturmuştur. Varsayımsal sorularda, yolculuk algısında eşdeğerlik sağlamak için, öğrencilerin kayda değer bir kısmının yaşadığı, öğrenci odaklı sosyal aktivite bakımından yoğun olan Bornova ilçesi ile Tınaztepe Kampüsü arasında yaptıkları yolculuklar için cevaplamaları istenmiştir. İkinci kısmın ilk bölümünde katılımcılardan, sınava geliş, derse geliş ve eve dönüş yolculuk amaçları için farklı güvenilirlik algıları yaratabilecek üç toplu ulaşım alternatifi arasından tercih yapmaları istenmiştir. Yolculuk amacı, ulaşım ana planı gibi modelleme çalışmalarında genellikle ev uçlu iş, ev uçlu eğitim ve ev uçlu olmayan gibi sınıflara bölünmektedir. $\mathrm{Bu}$ anket çalışmasında katılımcılara aktarılan yolculuk amaçlarının tamamı, ana plan model mantığına göre ev uçlu eğitim sınıfına girmektedir. Çalışmada, yolculuğun yönüne ve sonunda dâhil olunan aktiviteye göre önem düzeyini belirlemek için yolculuk amacı bakımından daha farklı bir amaç sınıflandırması yapılmıştır. Amaçlara göre sunulan ulaşım türleri aşağıdaki gibidir:

- Otobüs ile aktarmasız yolculuk (0)

- Metro-banliyö - otobüs aktarmalı yolculuk (MBO)

- Metro-otobüs aktarmalı yolculuk (MO)

Tablo 1. Açıklayıcı değişkenleri olușturan anket soruları ve seçenekler

\begin{tabular}{|c|c|}
\hline Anket sorusu & Seçenekler \\
\hline Cinsiyet & $\begin{array}{l}\text { a) Bayan } \\
\text { b) Erkek }\end{array}$ \\
\hline Yaş & $\begin{array}{l}\text { a) } 18 \text { 'den az } \\
\text { b) } 18-21 \\
\text { c) } 22-25 \\
\text { d) } 25 \text { 'den fazla }\end{array}$ \\
\hline $\begin{array}{l}\text { Üniversitedeki } \\
\text { yll }\end{array}$ & $\begin{array}{l}\text { a) İlk senem } \\
\text { b) } 2-3 \\
\text { c) } 4-5 \\
\text { d) Daha fazla } \\
\end{array}$ \\
\hline $\begin{array}{l}\text { Şehirde } \\
\text { bulunma }\end{array}$ & $\begin{array}{l}\text { a) } 1 \text { yıldır } \\
\text { b) 2-4 yıldır } \\
\text { c) 4-10 yıldır } \\
\text { d) } 10 \text { yıldan fazla }\end{array}$ \\
\hline Yaşadığı ilçe & $\begin{array}{l}\text { a) Buca } \\
\text { b) Bornova } \\
\text { c) Karşıyaka } \\
\text { d) Hatay } \\
\text { e) Gaziemir } \\
\text { f) Diğer }\end{array}$ \\
\hline $\begin{array}{l}\text { Toplu taşıma } \\
\text { (TT) kullanıcısı } \\
\text { mı? }\end{array}$ & $\begin{array}{l}\text { a) Evet } \\
\text { b) Kendi aracımla } \\
\text { c) Yakında oturuyorum }\end{array}$ \\
\hline $\begin{array}{l}\text { TT kullanma } \\
\text { sıklığı }\end{array}$ & $\begin{array}{l}\text { a) Her gün } \\
\text { b) Hafta içi her gün } \\
\text { c) Haftada birkaç gün } \\
\text { d) Hafta sonları } \\
\text { e) Kullanmıyorum }\end{array}$ \\
\hline Aktarma sayısı & $\begin{array}{l}\text { a) Tek araçla geliyorum } \\
\text { b) } 1 \\
\text { c) } 2 \\
\text { d) Daha fazla } \\
\text { e) Toplu tașıma }\end{array}$ \\
\hline Aktarma taşıtı & $\begin{array}{l}\text { a) Otobüs } \\
\text { b) Metro } \\
\text { c) Banliyöo } \\
\text { d) Vapur } \\
\text { e) Dolmuş } \\
\text { f) Aktarma yapmiyorum }\end{array}$ \\
\hline $\begin{array}{l}\text { Tür seçim } \\
\text { etkeni }\end{array}$ & $\begin{array}{l}\text { a) Güvenilirlik } \\
\text { b) Konfor } \\
\text { c) Kısa süre } \\
\text { d) Aktarmasız olması } \\
\text { e) Ekonomik olması }\end{array}$ \\
\hline
\end{tabular}


M. Özuysal ve D. Kaya / Kent İçi Ulaşımda Yolculuk Amacına Bağlı Güvenilirlik Algısının İncelenmesi: Tinaztepe Kampüsü Öğrenci Erişimi Örneği

Şehir içi güzergâhı kullanan bir hattın önerildiği ilk seçenek, aktarmasız olması yönünden konfor sağlarken, ayakta yolculuk yapma ihtimali bakımından konforsuzluk da içermekte; yolculuk süresi, trafik ve biniş yoğunluğuna bağlı olarak bir miktar değişebilmektedir. İkinci seçenek, iki adet aktarma içermekle beraber, yolculuğun büyük bir kısmı raylı sistemler üzerinde yapıldığından yüksek güvenilirlik sağlamaktadır. Üçüncü alternatif hem bir aktarma içermekte, hem de Bornova'dan yapılan yolculuğun büyük bir kısmı yine otobüs ile gerçekleşmektedir. Dolayısıyla, yolculuk süresi güvenilirliği bakımından en düșük alternatif olarak algılanma ihtimali yüksektir. Tür seçimi için oluşturulan çoklu lojistik regresyon modellerinde son seçenek karşılaştırma kategorisi olarak alınmış, böylece katılımcıların hangi sebeplerle daha yüksek güvenilirlik sunan ulaşım türlerine yöneldiği belirlenmeye çalışılmıştır.

Tür seçimi sorularının ardından, katılımcıların yolculuk süresi güvenilirliği algısını ortaya çıkarmak amacıyla, farklı düzeyde güvenilirlik riski içeren ve ikișer seçenekten oluşan üç farklı varsayımsal soru, sınava geliş ve eve dönüş amaçlı yolculuklar için ayrı ayrı (iki amaç ve üç senaryo için toplam 6 soru) olmak üzere sorulmuștur. $\mathrm{Bu}$ sorular, yolculuk süresinin değişiminde risk almayan veya daha az risk alan yolcuların güvenilirliğe daha çok önem verdiği hipotezine dayanmaktadır.

Kısaca "net güvenilirlik" adıyla değinilen birinci güvenilirlik senaryosu (GS1) sorularl, garanti bir yolculuk süresine karşı \%50 ihtimalle garanti sürenin yarısını kazanma veya kaybetme seçeneğini sunmakta olup seçenekler:

A) \% 50 ihtimalle $30 \mathrm{dk} ., \% 50$ ihtimalle $90 \mathrm{dk}$. sürecek yolculuk
B) $\% 100$ ihtimalle $60 \mathrm{dk}$. sürecek yolculuk

şeklindedir. İkinci seçenekte ilkindeki eşit olasılıklı aralığın ortalaması garanti süre olarak önerilmektedir. Düşük riskli güvenilirlik algısının ölçüldüğü ikinci senaryodaki (GS2) seçenekler:

A) \% 60 ihtimalle $60 \mathrm{dk} ., \% 40$ ihtimalle $75 \mathrm{dk}$. sürecek yolculuk

B) \% 80 ihtimalle $45 \mathrm{dk} ., \% 20$ ihtimalle 100 dk. sürecek yolculuk

şeklinde olup düşük baskın $1 / 4$ süre kazanma olasılığına karşılık yüksek baskın iki kattan fazla süre kazanma olasılığı sunmaktadır. İkinci seçenekte yolculuk, ilkine göre büyük olasılıkla (ilk seçeneğin alt sınırından) $15 \mathrm{dk}$. daha kısa, küçük olasılıkla (ilk seçeneğin üst sınırdan) $15 \mathrm{dk}$. daha uzun olacaktır. Yüksek riskli güvenilirlik algısını değerlendirmeye yönelik üçüncü senaryoda (GS3) ise:

A) \% 60 ihtimalle $75 \mathrm{dk}$., \% 40 ihtimalle $100 \mathrm{dk}$. sürecek yolculuk

B) \% 20 ihtimalle $45 \mathrm{dk} ., \% 80$ ihtimalle 120 dk. sürecek yolculuk

seçenekleri sunulmuş olup düşük baskın 1/4 süre kazanma olasılığına karşılık yüksek baskın 2.5 kat süre kaybetme olasılığı önerilmektedir. İkinci seçenekte yolculuk, ilkine göre küçük olasılıkla (ilk seçeneğin alt sınırından) $30 \mathrm{dk}$. daha kısa, büyük olasılıkla (ilk seçeneğin üst sınırdan) $20 \mathrm{dk}$. daha uzun olacaktır. Anket sonuçlarına ilişkin temel bulgular Bölüm 3.1'de verilmiştir.

\section{2. Çoklu lojistik regresyon}

Regresyon yöntemleri, bir yanıt değişkeniyle bir veya daha fazla açıklayıcı değişken arasındaki ilişsiyi açlklayan herhangi bir veri analizinin ayrılmaz bir parçası haline gelmiştir. Bağımlı değişkeninin iki veya daha fazla ayrık değer alması, özellikle davranışsal 
M. Özuysal ve D. Kaya / Kent İçi Ulaşımda Yolculuk Amacına Bağlı Güvenilirlik Algısının İncelenmesi: Tinaztepe Kampüsü Öğrenci Erişimi Örneği

analizlerde sıkça karşılaşılan bir durumdur. Lojistik regresyon modeli, son yıllarda ayrık bağımlı değișkenlerin kullanıldığı birçok alanda standart bir analiz yöntemine dönüşmüştür [16]. Lojistik regresyon analizinin kullanım amacı, istatistikte kullanılan diğer model yapılandırma teknikleriyle aynı olup temel amaç, bağımlı ve bağımsız değişkenler arasındaki ilişkiyi, en az değişken ile en iyi uyuma sahip olacak şekilde tanımlayabilen, kabul edilebilir bir model kurmaktır [18, 19]. Lojistik regresyon, en küçük kareler algoritmalarına dayanan genel doğrusal modellerin özellikle doğrusallık, normallik, eş varyanslılık (homoscedasticity) gibi birçok kısıtlayıcı varsayımını gerektirmemektedir [20]. Bu çalışmada, çoklu yanıtlı (polytomous) ve çok değişkenli (multivariate) lojistik regresyon modelinden yararlanılmıștır. Model mantığı, basit ikili (dichotomous) lojistik regresyon mantığından türetilerek aşağıda aktarılmıştır.

Basit ikili lojistik regresyonda, bağımlı değişken Y "var" ve "yok" gibi iki kategoriye sahiptir ve model kurulmadan önce "1" ve "0" şeklinde sayısallaştırılmalıdır. $\quad \mathrm{X}$ açıklayıcı değişken ve $\varepsilon$ hata terimi olarak düşünülürse basit en küçük kareler modeli aşağıdaki gibi tanımlanabilmektedir:

$$
\begin{aligned}
& Y_{i}=\beta_{0}+\beta_{1} \cdot X_{i}+\varepsilon_{i} \\
& i=1,2, \ldots, n
\end{aligned}
$$

Burada $\mathrm{X}_{\mathrm{i}}$, "i"nci gözlem için açıklayıcı değişken, $Y_{i}$ Bernoulli dağılımlı ikili yanıt değişkenini ifade etmektedir. Hata teriminin beklenen ortalama değerinin "0" olduğu düşünülürse, yanıtın beklenen ortalama değeri:

$$
\begin{aligned}
& E\left[Y_{i}\right]=\beta_{0}+\beta_{1} . X_{i} \\
& i=1,2, \ldots, n
\end{aligned}
$$

olacaktır. Yi Bernoulli dağılımlı rastgele değişken olduğundan olasılık fonksiyonu aşağıdaki gibi yazılabilmektedir:

$$
\begin{aligned}
& f(Y ; \pi) \\
& =\left\{\begin{array}{rr}
\pi, & Y=1 \\
1-\pi, & Y=0
\end{array}\right.
\end{aligned}
$$

$\pi_{\mathrm{i}}, \mathrm{Y}_{\mathrm{i}}=1$ ve $1-\pi_{\mathrm{i}} \mathrm{Y}_{\mathrm{i}}=0$ olma olasillklarl ise Bernoulli rastgele yanıtı Y'nin beklenen değeri:

$$
\begin{aligned}
& E\left[Y_{i}\right]=\beta_{0}+\beta_{1} \cdot X_{i} \\
& =1\left(\pi_{i}\right)+0\left(1-\pi_{i}\right) \\
& =\pi_{i}
\end{aligned}
$$

olmaktadır. Yanıt değişkeninin beklenen değerinin $\quad 0-1$ aralığında olması istendiğinden lojistik dönüşüm uygulanması gerekmektedir:

$$
\begin{aligned}
& \pi_{i}=E\left[Y_{i}\right] \\
& =\frac{\exp \left(\beta_{0}+\beta_{1} \cdot X_{i}\right)}{1+\exp \left(\beta_{0}+\beta_{1} \cdot X_{i}\right)}
\end{aligned}
$$

Böylece doğrusal lojit model (logaritmik olasılıklar) aşağıdaki gibi elde edilebilmektedir:

$$
\begin{aligned}
& \operatorname{lojit}[\pi(x)]=g(x) \\
& =\ln \frac{\pi(x)}{1-\pi(x)} \\
& =\beta_{0}+\beta_{1} \cdot X_{i}
\end{aligned}
$$

Burada,

$$
\begin{aligned}
& \pi(x)=P(Y=1 \mid X=x) \\
& =1-P(Y=0 \mid X=x)
\end{aligned}
$$

olup doğrusal öngörücü yaklaşım ile lojit bağlantıyı sağlamaktadır $[21,22]$.

Çok değişkenli lojistik regresyon ise basitçe, katsayılarda doğrusal bağıntının "k" adet bağımsız değişken içeren şeklidir:

$$
\begin{aligned}
& \pi(x)=\left[\operatorname { e x p } \left(\beta_{0}+\beta_{1} \cdot X_{i 1}+\beta_{2} \cdot X_{i 2}\right.\right. \\
& \left.\left.+\cdots+\beta_{k} \cdot X_{i k}\right)\right] /\left[1+\exp \left(\beta_{0}\right.\right. \\
& \left.\left.+\beta_{1} \cdot X_{i 1}+\beta_{2} \cdot X_{i 2}+\cdots+\beta_{k} \cdot X_{i k}\right)\right]
\end{aligned}
$$


Çok yanıtlı lojistik regresyon, ulaşım planlamasında bireysel tür seçimi modellerinde sıkça kullanılan çoklu lojit modelin özel bir durumu olarak hesaplanabilmektedir $\quad[23,24]$. İkili lojistik modelin çok yanitlı modele dönüştürülmesi için bağımlı (yanıt) değişkendeki bir yanıt (genellikle ilk veya son yanit) referans kategorisi olarak atanmakta $(\mathrm{Y}=\mathrm{h}$ ) $)$, diğer kategorilere ait üyelik olasılıkları referans kategorisininki ile kıyaslanmaktadır. Bağımlı değișken $M$ sayıda kategoriye sahip ise M-1 adet model denkleminin hesaplanacağı anlamına gelmektedir. Her bir kategori için lojit olasıllık:

$$
\begin{aligned}
& g_{h}\left(X_{1}, X_{2}, \ldots, X_{k}\right) \\
& =\exp \left(\beta_{h}+\beta_{h 1} \cdot X_{1}\right. \\
& +\beta_{h 2} \cdot X_{2}+\cdots \\
& \left.+\beta_{h k} \cdot X_{k}\right) \\
& h=1,2, \ldots, M-1
\end{aligned}
$$

şeklinde ifade edilebilir. Burada $\mathrm{k}$ indisi, bağımsız değişken numarasını gösterirken $\mathrm{h}$ indisi, bağımlı değişken kategorisini göstermektedir. Seçilen referans kategori için $\mathrm{g}_{0}\left(\mathrm{X}_{1}, \mathrm{X}_{2}, \ldots, \mathrm{X}_{\mathrm{k}}\right)=1$ dir. Y'nin referans kategori dişındaki herhangi bir kategoride olma olasılı̆̆ı ise:

$$
\begin{aligned}
& P\left(Y=h \mid X_{1}, X_{2}, \ldots, X_{k}\right)= \\
& \frac{\exp \left(\beta_{h}+\beta_{h 1} \cdot X_{1}+\beta_{h 2} \cdot X_{2}+\ldots+\beta_{h k} \cdot X_{k}\right)}{1+\sum_{h=1}^{M-1} \exp \left(\beta_{h}+\beta_{h 1} \cdot X_{1}+\beta_{h 2} \cdot X_{2}+\ldots+\beta_{h k} \cdot X_{k}\right)}(10) \\
& h=1,2, \ldots, M-1
\end{aligned}
$$

olmaktadır. Referans kategori için olasılık:

$$
\begin{aligned}
& P\left(Y=h_{0} \mid X_{1}, X_{2}, \ldots, X_{k}\right)= \\
& \frac{1}{1+\sum_{h=1}^{M-1} \exp \left(\beta_{h}+\beta_{h 1} \cdot X_{1}+\beta_{h 2} \cdot X_{2}+\ldots+\beta_{h k} \cdot X_{k}\right)} \\
& h=1,2, \ldots, M-1
\end{aligned}
$$

şeklinde hesaplanmaktadır [24]. Çalışmada tür seçim modelleri 3 kategoriye sahip olduğundan çok yanıtlı lojistik regresyon ile, güvenilirlik senaryosu modellerinde ise ankette iki seçenek sorulduğundan ikili lojistik regresyon ile modellenmiştir. Tür seçimin modellenmesi için ankette sunulan yalnız otobüs, metro-banliyö aktarması ile metro-otobüs aktarması seçeneklerinden sonuncusu referans kategorisi olarak seçilmiştir.

Lojistik regresyon yönteminde ayrı çlktılar (0 veya 1) elde edilmesi gerektiğinden, model katsayılarının elde edilmesi doğrusal regresyon modelindeki gibi basit en küçük kareler yöntemi ile mümkün olmamaktadır. Model parametreleri, maksimum olabilirlik, iterasyonla ağırlıklandırılmış en küçük kareler, minimum lojit Ki-kare gibi yöntemlerle bulunabilmektedir [16]. Bu çalışmada, lojistik regresyon bağımsız değişkenlerine ait $\beta$ katsayıları, sıkça kullanılan bir yaklaşım olan Maksimum Olabilirlik Yöntemi ile elde edilmiștir.

Gözlem verisi içindeki bütün $\left(\mathrm{x}_{\mathrm{i}}, \mathrm{y}_{\mathrm{i}}\right)$ veri çiftinin birleştirilmiş olasılık fonksiyonu, model parametrelerine ait olabilirlik fonksiyonu $\quad\left(\mathrm{L}\left(\mathrm{b}_{0}, \mathrm{~b}_{1}\right)\right) \quad$ olarak tanımlanmaktadır. Tek bir noktaya ait olasılık yoğunluk fonksiyonu:

$$
\begin{aligned}
& P\left(Y=y_{i}\right)=f\left(y_{i}\right) \\
& =\pi\left(x_{i}\right)^{y_{i}}\left(1-\pi\left(x_{i}\right)^{1-y_{i}}\right.
\end{aligned}
$$

şeklinde ifade edilirse, birleşik olabilirlik fonksiyonu:

$$
\begin{aligned}
& L\left(\beta_{0}, \beta_{1}\right)=g\left(y_{1}, y_{2}, \ldots, y_{n}\right) \\
& =\prod_{i=1}^{n} f_{i}\left(y_{i}\right) \\
& =\prod_{i=1}^{n} \pi\left(x_{i}\right)^{y_{i}}\left(1-\pi\left(x_{i}\right)^{1-y_{i}}\right.
\end{aligned}
$$

şeklini almaktadır. $\mathrm{Bu}$ fonksiyonu maksimize edebilmek için her bir parametreye göre türevinin alınıp sıfira eşitlenerek çözülmesi gerekmektedir. $\mathrm{Bu}$ aşama, denklemin doğal logaritması 
M. Özuysal ve D. Kaya / Kent İçi Ulaşımda Yolculuk Amacına Bağlı Güvenilirlik Algısının İncelenmesi: Tinaztepe Kampüsü Öğrenci Erişimi Örneği

üzerinde aynı işlem uygulanarak Bu iki eşik değer her açılayıcı değişken basitleştirilebilmektedir: için sağlanana kadar iterasyonlar devam etmektedir [26].

$$
\begin{aligned}
& \ln L\left(\beta_{0}, \beta_{1}\right)= \\
& \sum_{i=1}^{n}\left\{y_{i} \ln \left(\pi\left(x_{i}\right)\right)+\left(1-y_{i}\right) \ln \left(1-\pi\left(x_{i}\right)\right)\right\}
\end{aligned}
$$

Olasılıksal yanıt değişkeni sadeleștirilirse:

$$
\begin{aligned}
& \ln L\left(\beta_{0}, \beta_{1}\right)= \\
& \sum_{i=1}^{n}\left\{\begin{array}{l}
y_{i}\left(\beta_{0}+\beta_{1} \cdot X_{i}\right) \\
-\ln \left(1+\exp \left(\beta_{0}+\beta_{1} \cdot X_{i}\right)\right)
\end{array}\right\}
\end{aligned}
$$

şekline dönüşmektedir. Burada her bir parametre için sıfıra eșitlenip çözülmesi gereken denklemler:

$$
\begin{aligned}
& \frac{\partial \ln L\left(\beta_{0}, \beta_{1}\right)}{\partial \beta_{0}} \\
& =\sum_{i=1}^{n}\left[y_{i}-\left(\beta_{0}+\beta_{1} \cdot X_{i}\right)\right]=0 \\
& \frac{\partial \ln L\left(\beta_{0}, \beta_{1}\right)}{\partial \beta_{1}} \\
& =\sum_{i=1}^{n} x_{i}\left[y_{i}-\left(\beta_{0}+\beta_{1} \cdot X_{i}\right)\right]=0
\end{aligned}
$$

şeklinde ortaya çıkmaktadır. Logaritmik olabilirlik fonksiyonu doğrusal ve kapalı bir forma sahip olmadığından parametrelerin 0'dan başlatılarak iteratif olarak değiştirildiği Newton-Raphson algoritması gibi yöntemler uygulanabilmektedir [25].

Çalışmada, çok değişkenli lojistik modeller IBM SPSS Statistics (v.24) paket yazılımı kullanılarak elde edilmiştir. Model açıklayıcı değişkenleri seçilirken "ileri kademeli" (forward stepwise) değișken ekleme yöntemi kullanılmıștır. $\mathrm{Bu}$ yöntemde her bir adımda olabilirlik oranı (Ki-kare) test sonucu 0.05'ten küçük olan değișkenler modele dâhil edilirken, değişkenler eklendikçe olabilirlik oranı testi 0.10 'un altına inen değişkenler modelden çıkarılmaktadır.
Lojistik regresyon model başarımını ifade etmek için birçok istatistiksel ölçüt geliștirilmiștir. Bunlardan en basiti sapma istatistiği (deviation) olup logaritmik olabilirlik fonksiyonun "-2" katı şeklinde hesaplanmaktadır. Eğer sonuç modelinin sapma istatistiği, yalnız sabit terim içeren modelin sapma istatistiğinden anlamlı derecede farklı ise açıklayıcı değişkenlerin, yanıt değişkenini tahmin etmede katkı sağladığı anlaşılmaktadır. Bunun için olabilirlik oranı (Ki-kare), yalnız sabitli ve sonuç modellerinin sapma istatistiklerinin farkı şeklinde hesaplanmakta, Ki-kare dağılımında iki modelin serbestlik derecesi farkına göre test edilmektedir [27].

İkinci bir başarım ölçütü, modelin veriye uyumunu sınamaya yöneliktir. Çalışmada uyum derecesini belirlemek için Pearson sapma istatistiği kullanılmıştır. $\mathrm{Bu}$ yaklaşım model tahminlerinin gözlem verilerinden farklı olup olmadığını sinamakta, farklılık belirgin değilse (anlamlılık \%5'in üzerinde ise) modelin uyum derecesinin iyi olduğu sonucuna varılmaktadır.

Lojistik regresyon model başarımının doğrusal regresyondaki gibi 0-1 aralığında tek bir istatistik ile ifade edilebilmesi için bazı yapay R-kare istatistikleri türetilmiştir. Cox ve Snell tarafından önerilen yapay R-kare, olabilirlik oranı (Ki-kare) ve $\mathrm{n}$ veri sayısına bağlıdır [28]:

$$
R_{C S}^{2}=1-\exp \left(\begin{array}{l}
(-2 M O F(\text { sonuc })- \\
\frac{(-2 M O F(\text { sabit }))}{n}
\end{array}\right)
$$

Ancak bu istatistik hiçbir zaman teorik maksimum "1" değerine 
ulaşamamaktadır. Bu durumu düzeltmek için Nagelkerke tarafından aşağıdaki iyileştirme önerilmiştir [27]:

$$
R_{N}^{2}=\frac{R_{C S}^{2}}{1-\exp \left(-\frac{-2 M O F(\text { sabit })}{n}\right)}
$$

McFadden tarafından önerilen diğer bir yapay R-kare istatistiği de aşağıdaki gibidir:

$$
\begin{aligned}
& R_{M F}^{2} \\
& =1-\frac{M O F(\text { sonuç })}{M O F(\text { sabit })}
\end{aligned}
$$

Genel başarım ölçütlerinden bir diğeri de başarılı tahmin oranıdır. Basitçe her bir gözleme karşılık tahmin edilen olasılığın tamsayıya yuvarlanmış değerinin ne oranda birbirine eșit olduğunu ortaya koymaktadır [27].

\section{Bulgular}

Anket verilerinin değerlendirilmesi, üç farklı tür seçim modeli ve altı farklı güvenilirlik senaryo modeline ilişkin bulgular bu bölümde üç ayrı başlık altında sunulmuştur.

\subsection{Anket sonuçları}

$\mathrm{Bu}$ bölümde, toplam 180 öğrenci katılımcı ile gerçekleştirilen, "belirtilen tercih" esaslı güvenilirlik algısı anketi sonuçlarından önemli bazı istatistikler sunulmuştur. Şekil 1'de, farklı güvenilirlik algıları oluşturan üç değişik toplu ulaşım seçeneğinin ulaşım amaçlarına göre tercih edilme yüzdeleri görülmektedir.

Otobüs ile aktarmasız yolculuk, en yüksek güvenilirliği sağlayan tür olduğundan tüm yolculuk amaçları için en çok tercih edilen tür olmuştur. Onu, orta düzeyde güvenilirlik sağlayabilecek metro-banliyö-otobüs aktarmalı yolculuk izlemiştir. Katılımcıların düşük güvenilir olan metro-otobüs aktarmasının özellikle sınava geliş amaçlı yolculuklarda oldukça az (\%3) tercih ederek aktarmasız seçeneğe yönelmesi, yolculuk amacının güvenilirlik algısında önemli olduğunu göstermektedir. Düşük güvenilir türün seçim oranının eve dönüşlerde kayda değer düzeyde olması da (\%14) bu durumun bir diğer göstergesidir.

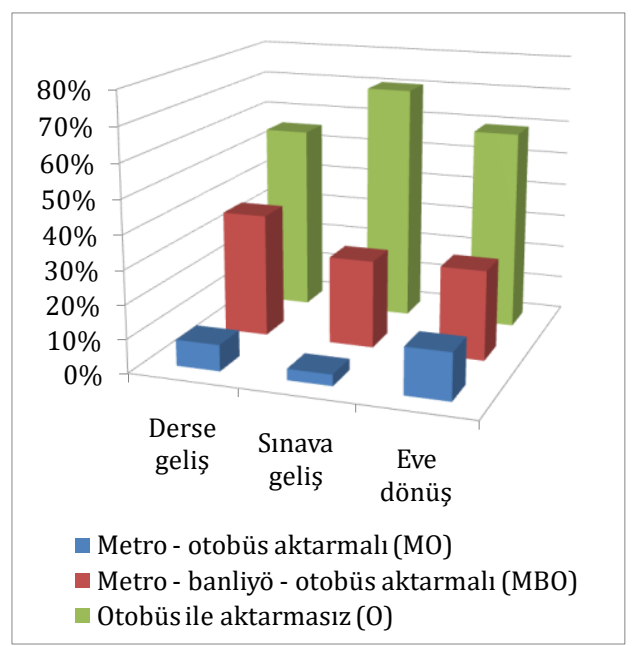

Şekil 1. Yolculuk amaçlarına göre tür seçim yüzdeleri

Her bir katılımcının sınava geliş ve eve dönüş amaçları arasında tür seçiminin ne düzeyde farklı olduğu Şekil 2 yardımıyla değerlendirilebilir. Yolculuk amacına göre tür seçimi etkilenmeseydi, şekilde köşegene denk gelen (MO-MO, MBO-MBO ve 0-0) sütunlarda yığılma olurken diğer sütunların hemen hemen boș kalması beklenirdi. $\mathrm{Bu}$ durumun gerçekleşmediği şekilden net olarak anlaşılmaktadır. Örneğin MBO türüyle sınava gelip aynı türle eve dönmeyi tercih eden katılımcılar \%9 iken, aktarmasız otobüsle (0) dönmeyi tercih edenler \%18 düzeyinde gözlemlenmiştir. Benzer şekilde gelişte ve dönüște otobüsü seçenler \%42 iken, toplamda \%59 olan otobüsle geliş içinden \%17'lik kesim dönüşte diğer türlere yönelmiştir. Sonuç olarak, yolculuğun yönü ve sonundaki aktivite türüne göre algılanan güvenilirlik, aynı birey için de belirgin şekilde ayırt edicidir. 
M. Özuysal ve D. Kaya / Kent İçi Ulaşımda Yolculuk Amacına Bağlı Güvenilirlik Algısının İncelenmesi: Tınaztepe Kampüsü Öğrenci Erişimi Örneği

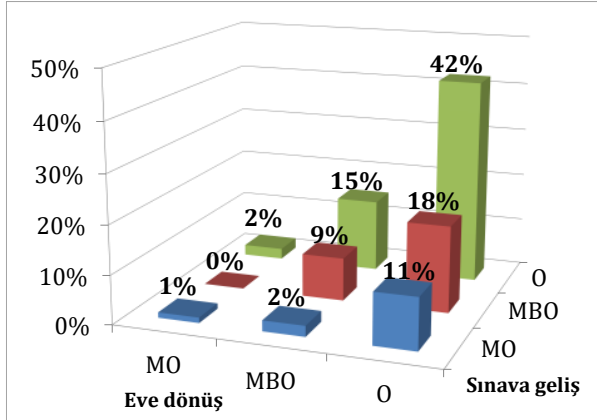

Şekil 2. Aynı katılımcılara ait sınava geliş ve eve dönüște ulaşım türü seçimlerinin yüzdesel dağılımı

Şekil 3'te, güvenilirlik senaryolarına verilen cevapların yolculuk amaçlarına göre çapraz karşılaştırmaları verilmiştir. Şekildeki grafiklerin amaçlara göre simetrik olmaması, her bir senaryoda güvenilirlik algısının yolculuk amacından etkilendiğini göstermektedir. GS1 grafiğinde, sınava gelişte garanti süreyi (B) tercih edenlerin eve dönüşte $\% 50$ sapma riski almaları çoğunluktadır (\%40). GS-2 grafiği eve dönüște riskli seçeneğe (B) yönelimin yüksek olduğunu (\%32+\%39=\%71), ancak aynı kişilerin sınava gelişte de B'yi seçerek risk alabildiğini (\%39) göstermektedir. Yüksek riskli GS3 senaryosunda ise her iki yolculuk amacı için göreceli düșük risk öneren A cevabı baskın olmuş (\%58), eve dönüşte dahi güvenilirlikte yüksek riske girme \%28'de kalmıştır. Beklendiği üzere, sınava gelirken yüksek risk alma önerisi toplamda sadece \%13’lük bir kabul görmüştür.

Güvenilirlik senaryolarının kendi aralarında nasıl bir algı oluşturduklarını anlayabilmek için senaryo cevaplarının çapraz tabloları yardımıyla bazı grafikler oluşturulmuştur. Şekil 4'te sınava geliş yolculukları için güvenilirlik senaryolarına verilen cevapların çapraz karşılaştırmaları görülmektedir. Net güvenilirlik algısına yönelik GS1 senaryosuna, garanti yolculuk süresi öneren B cevabını verenlerin büyük bir kısmı GS2 senaryosunda daha az risk içeren B'yi tercih etmiştir (\%38). Bununla birlikte GS1'de garanti süre öneren B cevabını verenlerin diğer bir önemli kesimi de GS2 senaryosunda A'ya göre daha çok risk öneren B cevabını (\%30) vermiştir. Dolayısıyla düşük riskli GS2 senaryosunun GS1 ilee ayrımı katılımcılar için çok net değildir. Başka bir deyișle katılımcılar, sınava geliş gibi önemli amaçlı yolculuklar için dahi düşük riskler alarak yolculuk süresini kısaltmayı göze alabilmektedir. GS1 ile yüksek riskli GS3 senaryoları arasındaki ayrım ise çok daha nettir. GS1'de garanti süre öneren B’yi seçen katılımcıların çoğu GS3'te de düşük risk öneren (B'ye göre) A'yı seçmiștir (\%62). Yüksek riske yönelmeme davranıșı tutarlı olmuștur. GS2-GS3 karşılaştırıldığında, en çok cevap çiftinin her iki senaryoda daha az riskli olan A seçeneğinde (\%47) olduğu görülmektedir. Dolayıyla iki senaryo için risk almama davranışında bir ortaklık söz konusudur. Ancak GS3'de az riskli alternatifi (A) seçip GS2'de çok riskli (B) alternatife yönelenlerin de payı yüksektir (\%39). Bu durum, GS2'nin yüksek riskinin, GS3'ün düşük riskine denk algılandığını göstermektedir. Sonuç olarak sınava geliş yolculukları için güvenilirlik algısının var ya da yok şeklinde doğrudan yorumlanmasının mümkün olmadığı, dolayısıyla algının parametrik bir model ile açıklanmasında yarar olduğu söylenebilir.

Şekil 5'teki eve dönüş amaçlı yolcukların GS1-GS2 cevapları karşılaştırıldığında, her iki senaryoda sunulan diğer seçeneğe göre daha riskli yolculuk süresi öneren (GS1'de A, GS2'de B) seçeneklerin ortak tercihi baskın gelmiş (\%47), risk alma davranışı örtüşmüştür. GS1-GS3 karşılaştırmasında ise, iki senaryo arasındaki risk farklılığı GS1-GS2 çiftine göre daha fazla olmasına rağmen, kayda değer bu tür bir davranış görülmemektedir. GS2-GS3 karşılaştırmasında, düşük riskli 
M. Özuysal ve D. Kaya / Kent İçi Ulaşımda Yolculuk Amacına Bağlı Güvenilirlik Algısının İncelenmesi: Tinaztepe Kampüsü Öğrenci Erişimi Örneği
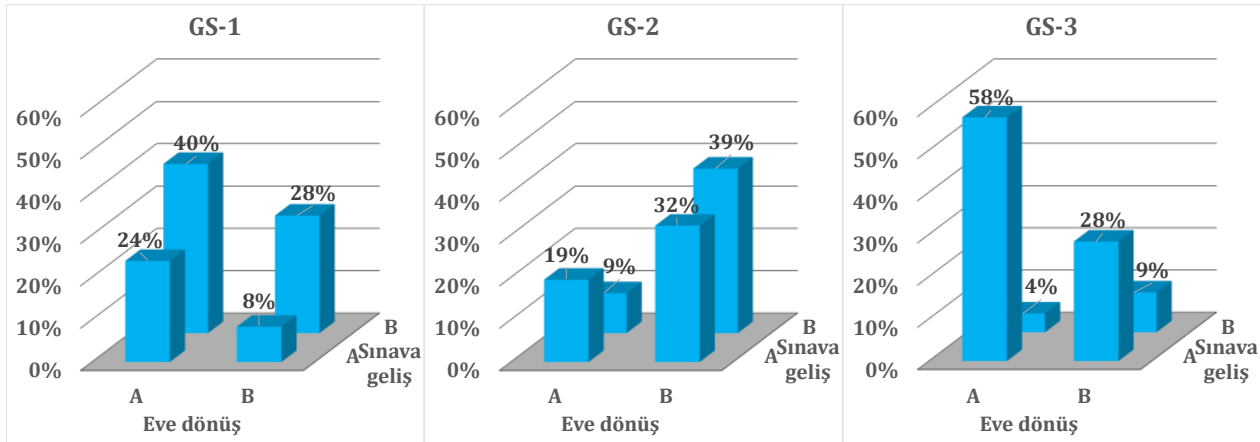

Şekil 3. Senaryo cevaplarının yolculuk amacına göre çapraz karşılaştırması
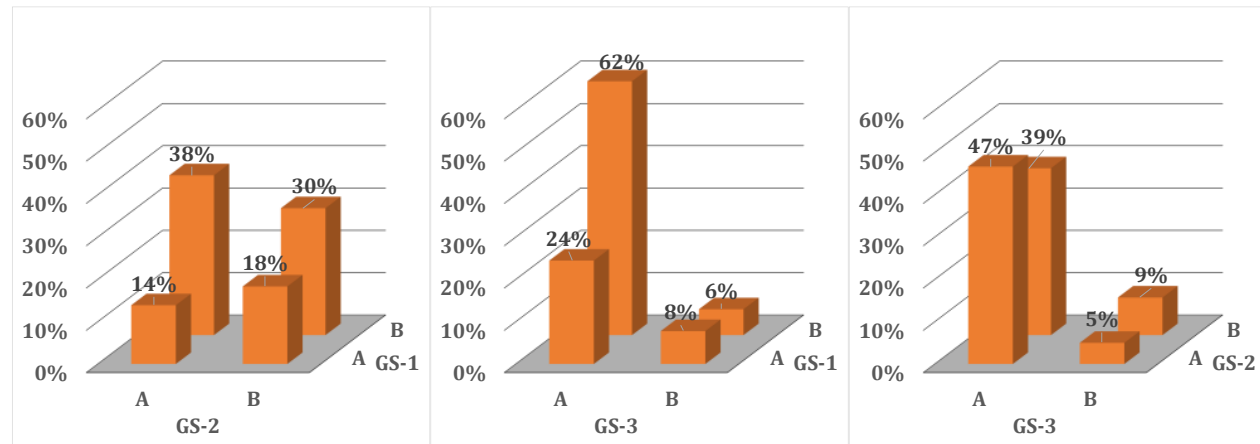

Şekil 4. Sınava geliş yolculuklarının senaryo cevaplarına göre çapraz karşılaştırması
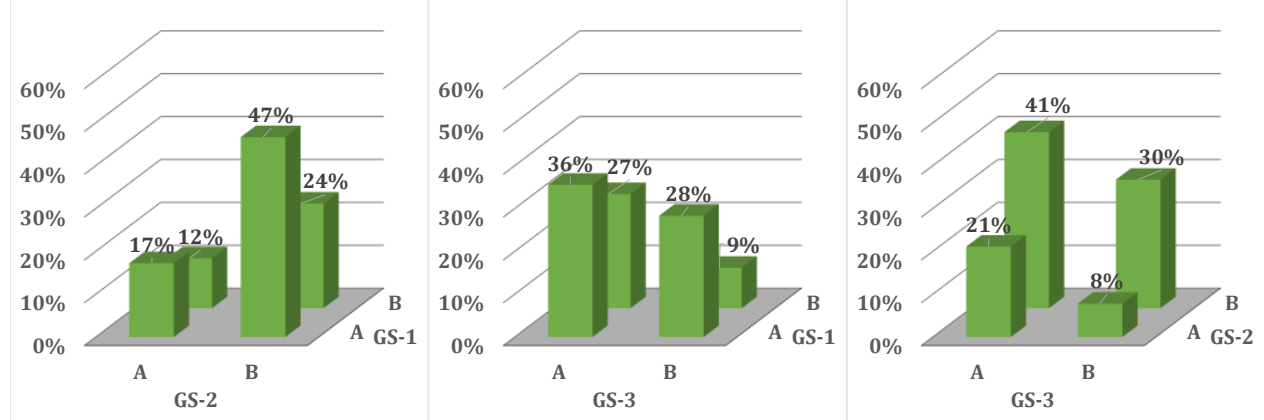

Şekil 5. Eve dönüş yolculuklarının senaryo cevaplarına göre çapraz karşılaștırması

senaryoda risk alıp (GS2:A) yüksek riskli senaryoda risk almayanların (GS3:A) çoğunlukta olduğu görülmektedir (\%41). Sınava geliş yolculuklarında olduğu gibi, GS2'nin yüksek riskinin, GS3'ün düşük riskine denk algılandığını söylenebilir. Dolayısıyla, doğrudan senaryo cevap dağllımlarına bakarak eve dönüşlerde güvenilirlikte risk büyüdükçe riskten kaçınma davranışını yakalayıp katılımcıları belirli algı sinıflarına ayırmak güçtür. Sonuç olarak algıda etkili parametrelerin mutlaka lojistik regresyon ve benzeri bir yaklaşımla irdelenmesi gerektiği açlktır.

\subsection{Tür seçim modelleri}

Farklı yolculuk amaçları için farklı güvenilirlik sunan ulaşım türleri arasındaki seçimde hangi parametrelerin etkili olduğunu sınamaya yönelik oluşturulan çoklu lojistik regresyon 
M. Özuysal ve D. Kaya / Kent İçi Ulaşımda Yolculuk Amacına Bağlı Güvenilirlik Algısının İncelenmesi: Tinaztepe Kampüsü Öğrenci Erişimi Örneği

modelleri, ikinci bölümde değinilen tüm başarım kriterleri bakımından iyi sonuçlar vermiştir. Tablo 2'de, derse gelirken, sınava gelirken ve eve dönerken seçilen türlere ait üç modelin başarım istatistikleri görülmektedir. Her üç modelde de yalnız sabit terim içeren olabilirlik fonksiyonu ile sonuç olabilirlik fonksiyonu değerleri arasında kayda değer farklılıklar oluşmuştur. Olabilirlik oranı (Ki-kare) anlamlılık testlerinin 10-4 ve altında olması da bunu göstermektedir. Uyum derecesi istatistiklerinin anlamlılık değerleri \%5'in oldukça üzerinde olduğundan, model tahminleri ile gözlemlerin farklılığının belirgin olmadığı anlașılmaktadır. Farklı araștırmacılar tarafından önerilen yapay R-kare değerleri, hiçbir zaman doğrusal regresyonda olduğu gibi teorik maksimum " 1 " değerine yaklaşamasa da uygulamada verilen örnekler mertebesindedir (bkz. [16]). Üç model karşılaştırıldığında en başarılı modelin \%70 tahmin oranı ile sınava geliş yolculuk amacına ait model olduğu görülmektedir. Tahmin oranları derse geliş ve eve dönüş modelleri için aynı olsa da diğer başarım istatistiklerine bakıldığında, derse geliș modelinin daha iyi sonuç verdiği görülmektedir. Bu durum geliş yolculuklarında daha net ve kestirilebilir bir tür tercihi davranıșı olduğunu göstermektedir. Model parametrelerine ait istatistikler Tablo 3'te görülmektedir. Olabilirlik oranı testleri ve Wald istatistiği bakımından modellerde ön plana çıkan değișkenler kalın ve italik yazı ile gösterilmiştir.

Tabloda görülen Wald istatistiği, basitçe parametre katsayısının standart sapmasına oranı olup "0"dan uzaklaştıkça parametrenin modele katkısının yüksek olduğu anlamına gelmektedir. Olabilirlik oranı testleri, parametre modele katılmadığında maksimum olabilirlik fonksiyonunun (MOF) hangi değeri alacağını göstermekte, bu değerin sonuç MOF değerinden kayda değer ölçüde büyük olması, bu parametre modele katılmadığında modelin yakınsayamayacağı, dolayısıyla parametrenin modele yüksek katkısı olduğu anlamına gelmektedir. MOF değerlerindeki farklılık Ki-kare dağılımına göre test edilerek anlamlılığının \%10'dan küçük olması beklenmektedir.

Tablo 2. Tür seçim modellerine ait başarım istatistikleri

\begin{tabular}{llrrr}
\hline Model türü: & & $\begin{array}{c}\text { Derse } \\
\text { gelirken }\end{array}$ & $\begin{array}{c}\text { Sinava } \\
\text { gelirken }\end{array}$ & $\begin{array}{c}\text { Eve } \\
\text { dönerken }\end{array}$ \\
\hline Sapma & Yalnız sabit terim: & 321.502 & 254.240 & 335.514 \\
(-2*MOF) & Sonuç modeli: & 280.191 & 205.170 & 301.040 \\
\hline Ki-kare: & & 41.312 & 49.070 & 34.474 \\
Ser. der.: & & 10 & 16 & 10 \\
Anlamlılık: & & $9.94 \mathrm{E}-06$ & $3.22 \mathrm{E}-05$ & $1.53 \mathrm{E}-04$ \\
\hline \multirow{2}{*}{ Pearson uyum } & Ki-kare: & 354.458 & 318.038 & 317.342 \\
derecesi & Ser. der.: & 342 & 336 & 342 \\
& Anlamlılı: & 0.310 & 0.752 & 0.827 \\
\hline \multirow{2}{*}{ Yapay } & Cox and Snell: & 0.205 & 0.239 & 0.174 \\
R-kare & Nagelkerke: & 0.246 & 0.315 & 0.206 \\
& McFadden: & 0.128 & 0.192 & 0.102 \\
\hline Başarılı & & $61.11 \%$ & $70.56 \%$ & $61.11 \%$ \\
tahmin oranı: & & & & \\
\hline
\end{tabular}


M. Özuysal ve D. Kaya / Kent İçi Ulaşımda Yolculuk Amacına Bağlı Güvenilirlik Algısının İncelenmesi: Tinaztepe Kampüsü Öğrenci Erişimi Örneği

Tablo 3. Tür seçim modellerine ait açıklayıcı değişken istatistikleri

\begin{tabular}{|c|c|c|c|c|c|c|c|c|c|c|}
\hline \multirow[b]{3}{*}{ Model Türü } & \multirow[b]{3}{*}{ i Model Parametreleri } & \multicolumn{6}{|c|}{ Değiş̧ken İstatistikleri } & \multirow{2}{*}{\multicolumn{3}{|c|}{$\begin{array}{c}\text { Olabilirlik Oranı } \\
\text { Testleri }\end{array}$}} \\
\hline & & \multicolumn{3}{|c|}{ Yalnız otobüs } & \multicolumn{3}{|c|}{ Metro-banliyö aktarmalı } & & & \\
\hline & & Katsayı & $\begin{array}{l}\text { Wald } \\
\text { Testi }\end{array}$ & $\begin{array}{c}\text { Anlam- } \\
\text { lillk }\end{array}$ & Katsayı & $\begin{array}{l}\text { Wald } \\
\text { Testi }\end{array}$ & $\begin{array}{l}\text { Anlam- } \\
\text { lillk }\end{array}$ & $-2 * \mathrm{MOF}$ & Ki-Kare & $\begin{array}{c}\text { Anlam } \\
\text { lilık }\end{array}$ \\
\hline \multirow{6}{*}{$\begin{array}{l}\text { Derse } \\
\text { gelirken } \\
\text { tür seçimi }\end{array}$} & Sabit terim & -0.27 & 0.04 & 0.84 & -17.11 & 249.26 & 0.00 & 280.19 & 0.00 & \\
\hline & Tür seçim etkeni (kısa süre) & 1.36 & 4.54 & 0.03 & 0.79 & 1.41 & 0.23 & 286.70 & 6.51 & 0.04 \\
\hline & TT kullanma sıkliğı (hiç) & 0.36 & 0.05 & 0.81 & 18.21 & & & 292.37 & 12.18 & 0.00 \\
\hline & Üniversitedekiyıl (4-5) & 2.29 & 4.34 & 0.04 & 2.18 & 3.78 & 0.05 & 287.41 & 7.22 & 0.03 \\
\hline & Cinsiyet & 15.87 & 0.00 & 0.99 & 16.73 & 0.00 & 0.99 & 294.22 & 14.03 & 0.00 \\
\hline & Aktarma sayısı (TT kullanmıyor) & 0.64 & 0.33 & 0.56 & -0.80 & 0.54 & 0.46 & 287.43 & 7.24 & 0.03 \\
\hline \multirow{9}{*}{$\begin{array}{l}\text { Sinava } \\
\text { gelirken } \\
\text { tür seçimi }\end{array}$} & Sabit terim & -3.81 & 0.00 & 1.00 & -21.42 & 0.00 & 0.98 & 205.17 & 0.00 & \\
\hline & Aktarma taşıtı (otobüs) & 14.76 & 0.00 & 0.99 & 15.21 & 0.00 & 0.98 & 211.14 & 5.97 & 0.05 \\
\hline & TT kullanma sıklı̆̆ (haftada 2-3) & 0.57 & 0.37 & 0.55 & 1.37 & 1.92 & 0.17 & 209.84 & 4.67 & 0.10 \\
\hline & Üniversitedeki yıl (2-3) & 0.51 & 0.26 & 0.61 & -0.51 & 0.24 & 0.63 & 211.26 & 6.09 & 0.05 \\
\hline & Aktarma sayısı (2) & 3.35 & 6.01 & 0.01 & 2.95 & 4.25 & 0.04 & 211.51 & 6.34 & 0.04 \\
\hline & Aktarma sayısı (TT kullanmıyor) & 1.62 & 2.00 & 0.16 & 0.15 & 0.02 & 0.90 & 213.99 & 8.82 & 0.01 \\
\hline & Aktarmataşıtı (yok) & 15.40 & 0.00 & 0.98 & 16.62 & 0.00 & 0.98 & 216.83 & 11.66 & 0.00 \\
\hline & Tür seçim etkeni (konfor) & 1.11 & 1.12 & 0.29 & 2.70 & 4.51 & 0.03 & 211.77 & 6.60 & 0.04 \\
\hline & Tür seçim etkeni (aktarma sayısı) & -14.30 & 0.00 & 0.99 & 1.62 & & & 217.34 & 12.18 & 0.00 \\
\hline \multirow{6}{*}{$\begin{array}{l}\text { Eve } \\
\text { dönerken } \\
\text { tür seçimi }\end{array}$} & Sabit terim & -1.10 & 0.00 & 1.00 & 14.10 & 0.00 & 0.95 & 301.04 & 0.00 & \\
\hline & Otomobil kullanıcısı & -13.44 & 0.00 & 0.95 & -11.22 & 0.00 & 0.96 & 318.08 & 17.04 & 0.00 \\
\hline & Yaşadığı ilçe (Gaziemir) & 2.04 & 4.93 & 0.03 & 0.67 & 0.61 & 0.44 & 306.87 & 5.83 & 0.05 \\
\hline & Şehirde bulunma (1 yıl) & 13.80 & 0.00 & 0.99 & -3.04 & & & 306.22 & 5.18 & 0.08 \\
\hline & Üniversitedeki yıl (4-5) & 1.55 & 6.54 & 0.01 & 0.85 & 1.73 & 0.19 & 310.39 & 9.35 & 0.01 \\
\hline & Toplu Taşıma (TT) kullanıcısı & -1.04 & 4.19 & 0.04 & -0.11 & 0.04 & 0.84 & 308.21 & 7.17 & 0.03 \\
\hline
\end{tabular}

Daha önce de değinildiği gibi, tür seçimi sorusundaki üçüncü seçenek olan metrootobüs aktarması referans kategori olarak alınmış, diğer aktarmasız otobüs ve metro-banliyö aktarmalı türler bu referansa kiyasla modellenmiştir. Kullanılan bütün bağımsız değișkenler kukla değişken olduğundan SPSS yazılımı bu değişkenlerin 0 veya 1 değeri alması durumlarından bir tanesini referans almaktadır. Tablo 3'teki değișken katsayıları, bütün bağımsız değişkenler için " 0 " (gerçekleşmeme) değerine göre elde edilen katsayılardır.

Derse gelirken seçilen ulașım türüne ait model sonuçları incelendiğinde, olabilirlik oranı testlerine göre, model parametrelerinin sonuç modelin yakınsamasına katkısının hepsi için anlamlı olduğu anlaşılmaktadır. Özellikle cinsiyet ve toplu ulaşım kullanmama değișkenlerinin olabilirlik fonksiyonuna katkısının büyük olduğu görülmektedir.
Cinsiyet $=0 \quad$ (bayan) parametresinin pozitif etkin çıkması, tür seçiminde daha güvenilir süre sağlayan aktarmasız otobüs ve metro-banliyö aktarmalı türlerin seçimine, bayan öğrencilerin daha net eğilim gösterdiğini sergilemektedir. Toplu ulaşım kullanma sıklığı (hiç) $=0 \quad$ (hiç cevabı vermeme) değişkeninin etkin çıkması da ancak toplu ulaşım kullanıcısı olanların tür seçim algısının modellenebileceğinin göstergesidir. Diğer taraftan, çoğu model parametresinin Wald testi anlamlılıklarının düşük olduğu görülmektedir. Bu durum, tür seçimini modellemede bu parametrelerin olabilirlik testine göre gerekli, ancak çoğu değiş̧ken katsayısının standart sapmasının yüksek olması sebebiyle yetersiz olduğunu göstermektedir. Üniversitedeki yll (4-5)=0 değişkeni her iki tür modelinde de anlamlı Wald istatistiğine sahip olan tek değişkendir. $\mathrm{Bu}$ durum, üniversitede 4 yıldan daha 
kısa süredir okumakta olan öğrencilerin tür seçimindeki güvenilirliğe daha çok önem verdiğini göstermektedir. Bunun sebebi, son yılına veya uzatma yllına devam eden öğrencilerin ders ve sınav yüklerinin ilk üç ylla kıyasla daha az olması ve kampüse nispeten daha az sıklıkta gelmeleri olabilir.

Sınava gelirken seçilen ulaşım türü modelinde, olabilirlik istatistiklerine göre en etkili değişkenler tür seçim etkeni (aktarma sayısı) $=0$ ve aktarma sayısı (toplu taşıma kullanmıyor) $=0$ cevapları olmuştur. Dolayısıyla mutlaka toplu ulaşım kullanıp tür seçiminde etkin olarak aktarma sayısını beyan etmeyenlerin tür seçiminin, sınava geliş gibi daha önemli bir yolculuk amacı için daha net ortaya konabildiği anlaşılmaktadır. Aktarma sayısı (2) $=0$ değișkeninin her iki kategori modelinde de Wald istatistiği bakımından anlamlı çıkması, her ne kadar aktarma sayısı etkili seçim faktörü olarak beyan edilmese de tür seçim davranışının, 2'nin altında aktarma yapıldığında kestirilebilir olacağı sonucu ortaya çıkmaktadır. Tür seçim etkeni (konfor) $=0$ parametresi ise metro-banliyö aktarması kategorisinde Wald testi bakımından etkili çlkmıștır. Bu durum, yüksek önemli yolculukların tür seçiminde konforun çok fazla dikkate alınmıyor olduğunu göstermektedir.

Eve dönüş amaçlı yolculukların tür seçimi modelinde, otomobil kullanıcısı $=0$ ve üniversitedeki yıl (4-5)=0 cevapları en etkin çıkmıştır. Otomobil kullanıcısı olan ve üniversitede son yılları olan öğrencilerin, sunulan toplu ulaşım seçeneklerine göre tür seçim davranışının net bir şekilde kestirilemeyeceği anlaşılmaktadır.

\subsection{Güvenilirlik algısı modelleri}

Güvenilirlik senaryoları için geliștirilen 6 farklı modele ait başarım istatistikleri Tablo 4'te görülmektedir. Maksimum olabilirlik fonksiyonu bütün modeller için \%5'in altında Ki-kare anlamlılıkları vermiştir. Dolayısıyla modellerin yeterince yakınsadığ $\breve{l}_{\text {söylenebilir. }}$ Pearson uyum derecesi ve yapay R-kare istatistiklerine bakıldığında, sınava geliş amaçlı yolculuklar için en başarılı modelin yüksek riskli güvenilirlik senaryosuna (GS3) ait olduğu görülmektedir. Bölüm 3.1'deki grafiklerden de görüldüğü gibi, sınava geliş yolculuklarında yüksek riskli güvenilirlik çok fazla tercih edilmediğinden daha net bir eğilim ortaya çıkmakta, dolayısıyla yüksek riskli güvenilirliğin tercih edilmeme sebepleri daha belirgin kestirilebilmektedir. Eve dönüş amaçlı yolculuklardaki güvenilirlik senaryoları karşılaştırıldığında ise net güvenilirlik (GS1) modeli başarım olarak ön plana çıkmaktadır. Eve dönüş yolculuklarında risksiz seçeneğin tercih oranının \%36 düzeyinde olması, kayda değer güvenilirlik riski alındığını göstermekte, bu modele ait göreceli yüksek başarım, bu davranışın sebeplerinin ortaya konabildiğini ifade etmektedir.

Sınava gelişlerde güvenilirlik algısına ilişkin model parametrelerine ait istatistikler Tablo 5'te verilmiştir. Net güvenilirlik algısının sınandığı GS1 modelinde aktarma sayısı ( 2 üstü) $=0$ ve aktarma taşıtı (vapur) $=0$ cevapları, negatif katsayılar ile etkin bulunmuştur. Modelde risksiz güvenilirlik öneren $B$ seçeneğinin " 1 ", \%50 ihtimallerle daha kısa veya daha uzun yolculuk süreleri (B'deki sürenin \%50'si oranında) öneren A seçeneğinin " 0 " olarak sayısallaştırıldığı düşünülürse, 
M. Özuysal ve D. Kaya / Kent İçi Ulaşımda Yolculuk Amacına Bağlı Güvenilirlik Algısının İncelenmesi: Tinaztepe Kampüsü Öğrenci Erişimi Örneği

Tablo 4. Güvenilirlik senaryo modellerine ait başarım istatistikleri

\begin{tabular}{|c|c|c|c|c|c|c|c|}
\hline \multirow[b]{2}{*}{ Model türü: } & & \multicolumn{3}{|c|}{ Sinava gelirken } & \multicolumn{3}{|c|}{ Eve dönerken } \\
\hline & & GS1 & GS2 & GS3 & GS1 & GS2 & GS3 \\
\hline \multirow{2}{*}{$\begin{array}{l}\text { Sapma } \\
\left(-2^{*} \mathrm{MOF}\right)\end{array}$} & Yalnız sabit terim & 224.886 & 246.560 & 143.673 & 234.073 & 216.415 & 238.668 \\
\hline & Sonuç modeli: & 213.257 & 230.384 & 120.697 & 209.009 & 200.425 & 230.408 \\
\hline Ki-kare: & & 11.629 & 16.176 & 22.976 & 25.065 & 15.990 & 8.259 \\
\hline Ser. der.: & & 2 & 4 & 6 & 4 & 3 & 2 \\
\hline Anlamlılık: & & $2.98 \mathrm{E}-03$ & $2.79 \mathrm{E}-03$ & 8.05E-04 & $4.88 \mathrm{E}-05$ & $1.14 \mathrm{E}-03$ & $1.61 \mathrm{E}-02$ \\
\hline \multirow{3}{*}{$\begin{array}{l}\text { Pearson } \\
\text { uyum } \\
\text { derecesi }\end{array}$} & Ki-kare: & 172.632 & 173.155 & 149.144 & 169.028 & 177.000 & 181.139 \\
\hline & Ser. der.: & 174 & 172 & 170 & 172 & 173 & 174 \\
\hline & Anlamlılık: & 0.515 & 0.461 & 0.874 & 0.550 & 0.402 & 0.340 \\
\hline \multirow{3}{*}{$\begin{array}{l}\text { Yapay } \\
\text { R-kare }\end{array}$} & Cox and Snell: & 0.063 & 0.086 & 0.120 & 0.130 & 0.085 & 0.045 \\
\hline & Nagelkerke: & 0.087 & 0.115 & 0.217 & 0.178 & 0.122 & 0.061 \\
\hline & McFadden: & 0.051 & 0.065 & 0.158 & 0.106 & 0.074 & 0.035 \\
\hline $\begin{array}{l}\text { Başarılı } \\
\text { tahmin oral }\end{array}$ & & $70.56 \%$ & $57.78 \%$ & $85.00 \%$ & $69.44 \%$ & $72.78 \%$ & $65.00 \%$ \\
\hline
\end{tabular}

Tablo 5. Sınava gelirken güvenilirlik algısı modellerine ait açıklayııı değişken istatistikleri

\begin{tabular}{|c|c|c|c|c|c|c|c|}
\hline \multirow[b]{2}{*}{ Model türü } & & \multicolumn{3}{|c|}{ Değișken Değerleri } & \multicolumn{3}{|c|}{ Olabilirlik Oranı Testleri } \\
\hline & & Katsayı & Wald testi & Anlamlılık & $-2 *$ MOF & Ki-Kare & Anlamlılık \\
\hline \multirow{3}{*}{ GS-1 } & Sabit terim & 33.841 & 42314.071 & 0.000 & 213.257 & 0.000 & \\
\hline & Aktarma sayısı (2 üstü) & -17.337 & & & 220.308 & 7.051 & 0.008 \\
\hline & Aktarma taşıtı (vapur) & -17.337 & & & 217.983 & 4.726 & 0.030 \\
\hline \multirow{5}{*}{ GS-2 } & Sabit terim & 18.217 & 369.531 & 0.000 & 230.384 & 0.000 & \\
\hline & Tür seçim etkeni (güvenilirlik) & -1.253 & 6.525 & 0.011 & 237.748 & 7.364 & 0.007 \\
\hline & Yașadığı ilçe (Gaziemir) & -1.301 & 3.095 & 0.079 & 233.921 & 3.537 & 0.060 \\
\hline & Aktarma taşıtı (vapur) & -17.109 & & & 234.920 & 4.536 & 0.033 \\
\hline & Tür seçim etkeni (aktarma sayısı) & 1.346 & 4.238 & 0.040 & 235.184 & 4.800 & 0.028 \\
\hline \multirow{7}{*}{ GS-3 } & Sabit terim & 2.781 & 3.041 & 0.081 & 120.697 & 0.000 & \\
\hline & Tür seçim etkeni (güvenilirlik) & -1.675 & 2.345 & 0.126 & 124.161 & 3.464 & 0.063 \\
\hline & Aktarma sayısı (1) & 0.934 & 3.672 & 0.055 & 124.403 & 3.707 & 0.054 \\
\hline & Cinsiyet & -0.922 & 2.982 & 0.084 & 123.608 & 2.912 & 0.088 \\
\hline & Şehirde bulunma (10 yıldan fazla) & -2.177 & 3.865 & 0.049 & 127.035 & 6.338 & 0.012 \\
\hline & TT kullanma sıklığı (haftaiçi) & 1.367 & 3.767 & 0.052 & 124.104 & 3.407 & 0.065 \\
\hline & Aktarma taşıtı (metro) & 1.635 & 10.001 & 0.002 & 131.047 & 10.351 & 0.001 \\
\hline
\end{tabular}

kampüse uzak bir ulaşım türü olan vapuru kullanan ve 2 'den fazla aktarma yapan öğrencilerin A seçeneğine yöneldiği, bu soruları olumsuz yanıtlayanların $B$ seçeneğine yöneldiği söylenebilir. Sonuç olarak, ulaşımda çok aktarmalı ve düşük güvenilir alternatifleri kullananlar, daha riskli ancak süre kazanma olasıllğı sunan seçenekleri tercih edebilmektedir.

Orta riskli seçenekler sunan GS2 senaryosuna ait sınava geliş modelinde tür seçimi etkeni (güvenilirlik)=0 ve (aktarma sayısı) $=0$ cevapları en etkili parametreler olmuștur. Modele göre, güvenilirliği tür seçiminde önemseyenler negatif katsayı ile, aktarma sayısını önemsemeyenler ise pozitif katsayı ile B seçeneğine yönelmiştir. Senaryoda, B seçeneği büyük olasılıkla A'nın alt sınırından $15 \mathrm{dk}$. daha kısa, küçük olasılıkla da A'nın üst sınırından $15 \mathrm{dk}$. daha uzun yolculuk süreleri önermektedir. Dolayısıyla sinava gelişlerde güvenirlik bakımından düşük risk alabilme davranışı, güvenilirliğe verilen önemle paralel, aktarma sayısına verilen önemle ters orantılıdır. Sonuç olarak öğrenciler sınava gelişlerinde, 
M. Özuysal ve D. Kaya / Kent İçi Ulașımda Yolculuk Amacına Bağlı Güvenilirlik Algısının İncelenmesi: Tınaztepe Kampüsü Öğrenci Erişimi Örneği

güvenilirliğe önem verseler dahi, aktarma sayısına bakmaksızın düşük riskler alabilmektedir. Ancak bu senaryoya verilen cevapların iki seçenek için birbirine oldukça yakın olması (A:\%52-B:\%48) ve başarılı tahmin oranının diğer senaryo modellerine kıyasla en düșük olması (\%58) sebebiyle, model çıkarımlarının dikkatli yapılması gerekmektedir.

Sınava geliş yolculuklarında yüksek riskli güvenilirlik senaryosuna (GS3) ait modelde ise şehirde bulunma (10 yıldan fazla)=0, aktarma taşıtı (metro) $=0$ ve aktarma sayısı (1)=0 cevapları etkin parametreler olmuștur. Bunlardan șehirde bulunma değișkeni negatif katsayıya sahipken diğerleri pozitif ișaretlidir. Dolayısıyla șehirde 10 yıldan fazla zamandır bulunan, toplu taşımada metro kullanmayan ve 1'den farkl aktarma yapan öğrencilerin, yüksek riskli seçenek sunan "B" cevabına yöneldiği görülmektedir. Şehirde uzun süredir yașıyor olmak, toplu ulașım olanakları hakkında daha tecrübeli olmak, metro aktarması yapmamak ise kent merkezine hızlı bir ulaşım türü ile gidebiliyor olmamak anlamına gelmektedir. Dolayısıyla yüksek güvenilir seçeneklerden yararlanamıyor olmak ve şehirdeki tecrübe, yolculuk süresinde risk alabilmeyi beraberinde getirmektedir. 1'den farklı aktarma yapmak, 2 veya üzerinden aktarma tecrübe eden öğrenci sayısının düşük gözlemlendiği (\%12) düşünülürse, aktarma kullanmıyor olmanın güvenilirlikte yüksek risk alabilmeye sebep olduğu söylenebilir.

Eve dönüş amaçlı yolculuklar için güvenilirlik algısı modellerine ait parametre istatistikleri Tablo 6'da görülmektedir. Net güvenilirlik algısını sınayan GS1 senaryosu için üniversitedeki yıl (2-3)=0 ve aktarma sayısı (2 üstü) $=0$ cevapları, pozitif katsayılar ile risksiz "B" alternatifinin seçiminde etkin olmuştur. 2 ve altında aktarma yapanların risksiz seçeneğe yönelmesi, çok aktarmalı yolculuk yapanlara göre eve dönüs yolculuklarında bile güvenilirliğe daha çok önem verdikleri şeklinde yorumlanabilmektedir. Üniversitede ilk veya son yılını okuyan öğrenciler için de eve dönüş yolculuk süresinde risk almama söz konusudur. Üniversitede genellikle 2 . ve 3 . sınıf öğretim programları daha yoğun olduğundan, öğrenciler ders ve ders dıșı aktiviteler için kampüste daha çok vakit geçirmekte, bu yüzden eve dönüş süresinin toplam aktivite süresine oranı düșük kalmaktadır. Dolayısıyla yolculuk süresi güvenilirliğinde riskli alternatife yönelme davranışı, 2. ve 3 . sınıf öğrencilerinde bu senaryo için daha baskındır.

GS2 senaryosunda ise eve dönüș yolculukları için, "A"ya göre düşük riskli süreci kazancı öneren "B" alternatifinin seçimi üzerindeki en etkin parametre, pozitif katsayılı tür seçim etkeni (kısa süre)=0 cevabı bulunmuştur. Kisa süreye önem vermeyen kesimin eve dönüşte düşük riskle 100 dk.'ya kadar uzayabilecek "B" alternatifine yönelmesi beklenen bir sonuçtur.

Yüksek riskli GS3 eve dönüş senaryoları modelinde otomobil kullanıcısı $=0$ cevabı, negatif katsayı ile en etkin değișken olmuştur. Dolayısıyla otomobil kullanıcısı olmayanlar, senaryoda daha garanti süre sunan " $A$ " seçeneğine yönelmiș, yüksek riski tercih etmemiștir. Diğer bir deyișle, ulașım alternatifleri içinde otomobile de erişebilenler, yüksek riskli "B" alternatifini seçebilmişlerdir. Dolayısıyla, düzenli toplu taşıma kullanıcıları, eve dönüş yolculuklarında da güvenilirliğe daha çok önem vermekte, alıştıkları süreden yüksek sapmalara sebep olacak seçeneklere sicak bakmamaktadır. 
M. Özuysal ve D. Kaya / Kent İçi Ulaşımda Yolculuk Amacına Bağlı Güvenilirlik Algısının İncelenmesi: Tinaztepe Kampüsü Öğrenci Erişimi Örneği

Tablo 6. Eve dönerken güvenilirlik algısı modellerine ait açıklayıcı değişken istatistikleri

\begin{tabular}{|c|c|c|c|c|c|c|c|}
\hline & & \multicolumn{3}{|c|}{ Değişken Değerleri } & \multicolumn{3}{|c|}{ Olabilirlik Oranı Testleri } \\
\hline \multicolumn{2}{|c|}{ Model türü } & Katsayı & Wald testi & Anlamlılık & $-2 * \mathrm{MOF}$ & Ki-Kare & Anlamlılık \\
\hline \multirow{5}{*}{ GS-1 } & Sabit terim & -14.871 & 0.000 & 0.988 & 209.009 & 0.000 & \\
\hline & Aktarma taşıtı (dolmuş) & -15.703 & 0.000 & 0.987 & 214.915 & 5.906 & 0.015 \\
\hline & Aktarma sayısı (2 üstü) & 28.893 & & & 215.032 & 6.024 & 0.014 \\
\hline & Yaşadığı ilçe (Gaziemir) & 1.449 & 3.795 & 0.051 & 213.071 & 4.063 & 0.044 \\
\hline & Üniversitedeki yıl (2-3) & 1.207 & 10.583 & 0.001 & 219.809 & 10.800 & 0.001 \\
\hline \multirow{4}{*}{ GS-2 } & Sabit terim & 32.445 & 13004.027 & 0.000 & 200.425 & 0.000 & \\
\hline & Tür seçim etkeni (kısa süre) & 1.006 & 7.937 & 0.005 & 208.839 & 8.414 & 0.004 \\
\hline & Şehirde bulunma (1 yıl) & -17.220 & & & 203.841 & 3.416 & 0.065 \\
\hline & Aktarma taşıtı (vapur) & -16.766 & & & 205.813 & 5.388 & 0.020 \\
\hline \multirow{3}{*}{ GS-3 } & Sabit terim & 0.974 & 2.649 & 0.104 & 230.408 & 0.000 & \\
\hline & Otomobil kullanıcısı & -1.409 & 5.098 & 0.024 & 236.612 & 6.204 & 0.013 \\
\hline & Şehirde bulunma (10 yıldan fazla) & 0.947 & 4.255 & 0.039 & 234.788 & 4.380 & 0.036 \\
\hline
\end{tabular}

\section{Tartışma ve Sonuç}

Metropol kentlerde günlük hayatımızın önemli bir bileșeni olan yolculuk süresi belirsizliği, ulaşım sisteminin de en kritik başarım ölçütünü oluşturmaktadır. Çalışmada, yolculuk süresi güvenilirliğinin kişisel faktörler ve farklı yolculuk amaçları için ne şekilde algllandığı irdelenmiş, böylece ulaşım talep modellerine ve dolayısıyla kentsel ulaşım yatırım kararlarına nasıl yansıtılması gerektiği incelenmiştir.

Tür seçimine yönelik anket sonuçları, sunulan varsayımsal ulaşım türlerinin beklenen şekilde bir güvenilirlik algısını oluşturduğunu göstermiştir. Yolculuk amaçlarının da tür seçiminde gözle görülür bir etken olduğu anlaşılmıştır. Sınava geliş senaryolarında net güvenilirlik (GS1) ve yüksek riskli güvenilirlik (GS3) senaryolarının algısının risk almama bakımından net bir şekilde fark ettiği belirlenmiștir. Eve dönüş senaryolarında ise düşük riskli (GS2) ve yüksek riskli (GS3) senaryolarında ortak risk alma davranışı gözlemlenmiştir. Sonuç olarak güvenilirliğin aynı bireyler tarafından yolculuk amacına göre farklı algılandı̆̆ı ortaya konmuştur.
Farklı güvenilirlik algısı doğuran toplu ulaşım seçenekleri arasındaki tercihte etkili faktörlerin değerlendirilmesi amacıyla oluşturulan tür seçim modellerinde, sınava ve derse geliş amaçları için güvenilirliğe dayalı tür seçim algısının, eve dönüş yolculuklarına göre daha kestirilebilir olduğu anlaşılmıştır. Tür seçiminde farklı yolculuk amaçları için farklı parametrelerin ön plana çıkması, yolculuk amacının toplu ulaşım türleri tarafından sağlanan güvenilirlik algısında etkili ve bireysel özelliklere bağlı olduğu sonucunu doğurmaktadır. Çalışmada sunulan tür seçim modellerinden amaç, tür seçimini ulaşım talep modeli düzeyinde tahmin etmek olmamasina ve talep modellerinde toplanan ulaşım hane halkı anketi verilerine kıyasla çok daha basit bir veri kullanılmasına rağmen $\% 60$ ve üzerinde başarılı tahminler sağlanmıştır.

Sınava gelişte net güvenilirlik algısı modeli, çok aktarmalı ve düşük güvenilir alternatifleri kullanan yolcuların net güvenilirlikten ödün vererek daha kısa süre için risk alabildiklerini göstermiştir. Düşük riskli senaryoda ise güvenilirliğin ve aktarma 
sayısının tür seçiminde etken parametre olarak cevaplanması, daha güvenilir seçenekten düşük riskli seçeneğe yönelmelere sebep olmuştur. Dolayısıyla sınava gelirken bile yolculuk süresini düşük risk alarak kısaltma eğilimi yüksektir. Yüksek risk alma davranışının sinandığı GS3 senaryosunda ise aktarma için metroyu kullanmayanlar ile şehirde uzun süredir yaşayanların güvenilirlikte daha büyük risk alarak yolculuk süresini kısaltmak istedikleri ortaya çıkmıştır. Senaryolar türden bağımsız olup özel taşıtlı yolculuk olarak da düşünülebildiğinden, şehre hâkim olan özel taşıt kullanıcıları, kullanacakları güzergâhı eniyileyerek yolculuk süresini kısaltabilecekleri görüşündedir.

Eve dönüşte güvenilirlik algısını sınayan modellerden net güvenilirlik modelinde (GS1), çok aktarmalı yolculuk yapan ve kampüste daha çok vakit geçiren öğrencilerin, güvenilirlikte risk almayı (risksiz seçeneğe göre) tercih ettiği kanısına varılmıştır. Yolculuk süresi, toplam aktivite süresine oranla kısaldıkça ve hâlihazırda uzun yolculuklar gerçekleştirdikçe güvenilirlikten ödün vererek daha kısa süren alternatifler arama çabası yükselmektedir. Düşük riskli senaryoda ise yolculuk süresinin kısa olmasına önem vermeyen öğrencilerin eve dönüşte güvenirlikte risk alabildikleri ortaya çıkmaktadır. Eve dönüşte yüksek riskten kaçınma davranışında etkili parametre (GS3) otomobil kullanıcısı olmamak ile orantılıdır. Sınava geliş yüksek risk senaryosunda olduğu gibi, eve dönüş GS3 senaryosunda da özel taşıt kullanmak, yüksek riski göze alabilmek anlamına gelmektedir.

Sonuç olarak güvenilirliğin kişiden kişiye hatta aynı kişinin farklı amaçlı yolculuklarında dahi farklı algılandığı, dolayısıyla ulaşım talep modellerinde bir maliyet ağırlıklandırma bileşeni olarak değil; yaş, cinsiyet, gelir vb. gibi başlı başına bir sosyo-ekonomik parametre gibi değerlendirilmesi gerektiği anlaşılmıştır. Güvenilirlik algısında kişisel özellikler ile yolculuk amacının kayda değer düzeyde etkin olması, güvenilirliği arttırmaya yönelik raylı sistem veya gerçek zamanlı yolcu bilgilendirme sistemi gibi yatırımlara ilişkin kararlarda, güvenilirliği önemseyen kullanıcıların yoğun kullandığı güzergâhlara öncelik verilmesi gereğini ortaya koymaktadır.

Takip eden çalışmalarda, bu tür bir "belirtilen tercih" anket çalışmasının kent ölçeğinde bir örneklem ile yaygınlaştırılarak uygulanması, böylece yolculuk amacı ve sosyo-ekonomik açıdan daha geniş çaplı çıkarımlara ulaşılması düşünülmelidir. Ayrıca güvenilirlik algısının ulaşım talep modelindeki türel dağılım ve atama aşamalarına yansitılmasına yönelik yöntemler sınanmalıdır.

\section{Teşekkür}

$\mathrm{Bu}$ çalışma, TÜBİTAK tarafından desteklenen 112M117 no.lu ve "Akıllı Kart Verilerine Dayalı Güvenilirlik Ölçütlerinin Toplu Ulaşım Atama Modellerine Entegrasyonu" başlıklı araştırma projesinde yer alan bazı çalışmaları içermektedir. Bu bağlamda, sağladığı proje desteği için TÜBİTAK'a teşekkür ederiz.

\section{Kaynakça}

[1] Siu, W.Y. 2009. Reliability Based Transportation Network Studies. The Hong Kong University of Science and Technology, Doktora Tezi, 236s, Hong Kong.

[2] Small, K.A. 1982. The Scheduling of Consumer Activities: Work Trips, American Economic Review, Cilt. 72, s. 467-479. DOI: jstor.org/stable/1831545. 
M. Özuysal ve D. Kaya / Kent İçi Ulaşımda Yolculuk Amacına Bağlı Güvenilirlik Algısının İncelenmesi: Tinaztepe Kampüsü Öğrenci Erişimi Örneği

[3] Chen, X., Yu, L., Zhang, Y., Guo, J. 2009. Analyzing Urban Bus Service Reliability at the Stop, Route, and Network Levels, Transportation Research Part A, Cilt. 43, s. 722734. DOI: $10.1016 /$ j.tra.2009.07. 006.

[4] Turnquist, M.A., Bowman, L.A. 1980. The Effects of Network Structure on Reliability of Transit Service, Transportation Research, Cilt. 14B, s. 79-86. DOI: 10.1016/ 0191-2615(80)90034-X.

[5] Murat, Y.S., Uludağ, N. 2008. Bulanık Mantık ve Lojistik Regresyon Yöntemleri ile Ulaşım Ağlarında Rota Seçim Davranışının Modellenmesi, İMO Teknik Dergi, Cilt. 19 (2), s. 4363-4379.

[6] Doğan, G., Özuysal, M. 2017. Toplu Ulaşımda Bekleme Süresini Etkileyen Faktörlerin İncelenmesi: Güvenilirlik, Yolcu Bilgilendirme Sistemi ve Fiziksel Koşullar, İMO Teknik Dergi, Cilt. 28 (3), s. 7927 7954, DOI: 10.18400/ tekderg.307513.

[7] Liu, R., Sinha, S. 2007. Modelling Urban Bus Service and Passenger Reliability. The Third International Symposium on Transportation Network Reliability (INSTR), 19-20 Temmuz, The Hague, Netherlands, 2007.

[8] Abkowitz, M., Slavin, H., Waksman, R., Englisher, L., Wilson, N. 1978. Transit Service Reliability Report. USDOT Transportation Systems Center, Cambridge, MA.

[9] Özuysal, M., Uzunoğlu, U.Z.K., Akpulat, N., Çalıșkanelli, S.P., Tanyel, S., Ceylan, H. 2015. Akıllı Kart Verilerine Dayalı Güvenilirlik Ölçütlerinin Toplu Ulaşım Atama Modellerine Entegrasyonu. TÜBİTAK Projesi Final Raporu, 112M117, Ankara, 369s.
[10] Small. K.A., Noland, R., Chu X., Lewis, X. 1999. Valuation of Travel-Time Savings and Predictability in Congested Conditions for Highway User-Cost Estimation. NCHRP Report 431, Transportation Research Board, National Research Council, 74s.

[11] Brownstone, D., Small, K.A. 2005. Valuing Time and Reliability: Assessing the Evidence from Road Pricing Demonstrations, Transportation Research Part A, Cilt. 39, s. 279-293. DOI: 10.1016/j.tra.2004.11.001

[12] Liu, H.X., Recker, W., Chen, A. 2004. Uncovering The Contribution of Travel Time Reliability to Dynamic Route Choice Using Real-Time Loop Data, Transportation Research Part A, Cilt. 27, s. 435453. DOI: 10.1016/ j.tra.2004.03.003

[13] Orsi, F., Geneletti, D. 2014. Assessing the Effects of Access Policies on Travel Mode Choices in an Alpine Tourist Destination, Journal of Transport Geography, Cilt. 39, s. 21-35. DOI: 10.1016/ j.jtrangeo.2014.06.015.

[14] Sohoni, A.V., Thomas, M., Rao, K.V.K. 2017. Mode Shift Behavior of Commuters Due to the Introduction of New Rail Transit Mode, Transportation Research: Procedia, Cilt. 25C, s. 2607-2622. DOI: 10.1016/j.trpro.2017.05.311.

[15] Kou, W., Chen, X., Yu, L., Qi, Y., Wang, Y. 2017. Urban Commuters' Valuation of Travel Time Reliability Based on Stated Preference Survey: A Case Study of Beijing. Transportation Research Part A, Cilt. 95, s. 372-380. DOI: 10.1016/j.tra.2016.10.008 
M. Özuysal ve D. Kaya / Kent İçi Ulaşımda Yolculuk Amacına Bağlı Güvenilirlik Algısının İncelenmesi: Tınaztepe Kampüsü Öğrenci Erişimi Örneği

[16] Hosmer, D.W., Lemeshow, S. 2000. Applied Logistic Regression: Second Edition, Wiley Series in Probability and Statistics, Jonh Wiley and Sons Inc., New York, 528s.

[17] Lee-Gosselin, M. 1995. Scope and Potential of Interactive Stated Response Data Collection Methods. Conference on Household Travel Surveys: New Concepts And Research Needs, 12-15 Mart, Irvine, California.

[18] Atasoy, D. 2001. Lojistik Regresyon Analizinin İncelenmesi ve Bir Uygulaması. Cumhuriyet Üniversitesi, Sosyal Bilimler Enstitüsü, Yüksek Lisans Tezi, Sivas.

[19] Çokluk, Ö. 2010. Lojistik Regresyon Analizi: Kavram ve Uygulama, Kuram ve Uygulamada Eğitim Bilimleri, Cilt. 10 (3), s. 1357-1407.

[20] Silahl,, N. 2013. Applications of Logistic Regression with Missing Data. Dokuz Eylül Üniversitesi, Fen Bilimleri Enstitüsü, Yüksek Lisans Tezi, 76s.

[21] Agresti, A. 2002. Categorical Data Analysis (Second Ed). Wiley Series in Probability and Statistics, Wiley and Sons Inc., New York, 710s.
[22] Göksülük, D. 2011. Panelized Logistic Regression, Dokuz Eylül Üniversitesi, Fen Bilimleri Enstitüsü, Yüksek Lisans Tezi, 54s.

[23] DeMaris, A. 1992. Logit Modeling. Sage University Paper Series on Quantitative Applications in the Social Sciences, 07-086, Sage Publications, Newbury Park, CA. DOI: $10.4135 / 9781412984836$.

[24] Menard, S. 2002. Applied Logistic Regression Analysis: Second Edition. Sage University Paper Series on Quantitative Applications in the Social Sciences, 07-106, Sage Publications, Thousand Oaks, CA, 128s.

[25] Ben-Akiva, M., Lerman, S. R. 1985. Discrete Choice Analysis. The MIT Press, Cambridge, MA, 412s.

[26] SPSS. 2016. IBM SPSS Statistics Software Tutorial, IBM Corporation.

[27] Field, A. 2009. Discovering Statistics Using SPSS: Third Edition. Sage Publications, Thousand Oaks, CA, 752s.

[28] Cox, D. R., Snell. E. J. 1989. The Analysis of Binary Data, Second Edition, Chapman and Hall, London, 240s. 